Tropical Journal of Pharmaceutical Research April 2014; 13 (4): 601-606

ISSN: $1596-5996$ (print); 1596-9827 (electronic)

(C) Pharmacotherapy Group, Faculty of Pharmacy, University of Benin, Benin City, 300001 Nigeria.

All rights reserved.

Available online at http://www.tjpr.org

Original Research Article

http://dx.doi.org/10.4314/tjpr.v13i4.17

\title{
Determination of Amino Acids in Medicinal Plants from Southern Sonora, Mexico
}

\author{
Edgar F Moran-Palacio ${ }^{1}$, Orlando Tortoledo-Ortiz ${ }^{2}$, Grelda A Yañez-Farias ${ }^{1}$, Luis \\ A Zamora-Álvarez ${ }^{1}$, Norma A Stephens-Camacho ${ }^{3}$, José G Soñanez-Organis ${ }^{1}$, \\ Luisa M Ochoa-López ${ }^{1}$ and Jesús A Rosas-Rodríguez ${ }^{1 *}$ \\ ${ }^{1}$ Departamento de Ciencias Químico Biológicas y Agropecuarias, Universidad de Sonora Unidad Regional Sur, Apartado \\ Postal 85390, Navojoa, ${ }^{2}$ Coordinación de Nutrición, Centro de Investigación en Alimentación y Desarrollo A.C., Apartado \\ Postal 1735, Hermosillo 83000, ${ }^{3}$ Licenciatura en Nutrición Humana, Universidad Estatal de Sonora UES. Carretera \\ internacional a Huatabampo y Periférico S/N km. 5 Colonia Juárez, Navojoa, Sonora, México
}

*For correspondence: Email: jrosas@navojoa.uson.mx; Tel: +52 (642) 4259952 Ext 7057

Revised accepted: 2 February 2014

\begin{abstract}
Purpose: To analyze the amino acid contents of some plants used in traditional medicine in Southern Sonora, Mexico by using high performance liquid chromatography (HPLC).

Methods: The plant samples (Jutuki, Zizyphus obtusifolia A.Gray; Jito, Forchammeria watsonii Rose; Barchata, Lycium berlandieri Dunal; Citabaro, Vallesia glabra Link; Mangle Rojo, Rhizophora mangle L and Tatachinole, Tournefortia hartwegiana Steud) were dehydrated at room temperature and ground to a fine powder. Amino acid analysis was performed by reversed-phase HPLC. Elution was carried out with a gradient mobile phase of sodium acetate $0.1 \mathrm{M}$ and methanol (9:1). Samples were derived with ophthalaldehyde (OPA) and detected by fluorescence at 360(Ex)/455(Em) wavelengths.

Results: HPLC analysis resulted in a reliable detection and peak resolution. Tatachinole samples show the greater amino acid concentration $(7.83$ to $58.17 \mathrm{nM})$. Fifteen amino acids were detected in plant samples, with aspartic acid (Asp), glutamic acid (Glu), serine (Ser), glycine (Gly), alanine (Ala) and leucine (Leu) (43.55, 44.84, 29.60, 58.17, 43.05 and $38.73 \mathrm{nM}$, respectively) presenting the highest concentrations.

Conclusion: The amino acids - Asp, Glu, Ser, Gly, Ala and Leu - are naturally involved in osmolyte synthesis, cell metabolism, ammonia detoxification, antioxidant activity and alkaloid synthesis, suggesting that the therapeutic properties of these Southern Sonora plants may have some links to their amino acid composition.
\end{abstract}

Keywords: Amino acid profile, Medicinal plants, Osmolytes, Drought/saline stress

Tropical Journal of Pharmaceutical Research is indexed by Science Citation Index (SciSearch), Scopus, International Pharmaceutical Abstract, Chemical Abstracts, Embase, Index Copernicus, EBSCO, African Index Medicus, JournalSeek, Journal Citation Reports/Science Edition, Directory of Open Access Journals (DOAJ), African Journal Online, Bioline International, Open-J-Gate and Pharmacy Abstracts

\section{INTRODUCTION}

Amino acids are essential in the synthesis of proteins and precursors in the formation of secondary metabolism molecules [1] that participate in cell signaling, gene expression and homeostasis regulation [2], protein phosphorylation, synthesis of hormones and antioxidant capacity [3]. Also, amino acids participate in various physiological processes such as skeletal muscle function, atrophic conditions, sarcopenia and cancer [4,5].

Drought stress and saline are conditions that favor the accumulation of products of primary metabolism as osmolytes, amino acids and 
reducing sugars [3]. Also, the plants are adapted to several stress conditions such as high and low temperatures, high salt concentrations, exposure to heavy metals, ultraviolet radiation and drought stress as result of their continuous evolution [6]. The response of the plants results in the activation of mechanisms involved in the synthesis and accumulation of secondary metabolites responsible for the beneficial properties attributed to medicinal plants [7].

Traditional medicine practice entails the use of natural resources like plants, animals, water and minerals. The use of plants as an alternative for the treatment of renal, gastrointestinal, rheumatism, liver, anti-diabetes, amongst other diseases, has increased over the years [8]. The bioclimatic conditions of southern Sonora, Mexico allow the plants to accumulate compounds as an adaptive mechanism in response to stress [9]. The accumulation of primary metabolites for development of plants is well defined.

However, few studies focus on primary metabolites in plants naturally adapted to tolerate prolonged periods of drought stress/saline and the relationship with their therapeutic properties. To assess the relationship between the production of primary metabolites and their possible therapeutic properties, we analyzed the amino acid profile of plants from southern Sonora (Mexico) used in traditional medicine. The study of compounds generated by plants as a result of defense mechanisms permit understanding of the molecular mechanism involved in their medicinal properties.

\section{EXPERIMENTAL}

\section{Chemicals}

2-mercaptoethanol, $o$-phthalaldehyde (OPA) and a-aminobutyric acid were purchased from Sigma (Sigma-Aldrich, St. Louis, MO, USA). Amino acid standard was purchased from PIERCE (no. 20089).

\section{Plant materials}

The root, leaf and bark of plants were collected from Southern Sonora region, northwest of Mexico, during May 2010 (Table 1). The plant samples were authenticated by Professor José Jesús Sánchez Escalante at Universidad de Sonora Herbarium, and voucher specimens were preserved in the laboratory for future reference. Plant samples were washed with distilled water and dried at room temperature. Completely dehydrated samples were ground to a fine powder using an electric mill (Thomas Scientific Model 3383-L10), and used for amino acid analysis.

Table 1: List of plants from Southern Sonora Mexico used to amino acid screening

\begin{tabular}{lcc}
\hline Plant & Common name & Voucher \\
\hline $\begin{array}{l}\text { Rhizophora mangle L } \\
\begin{array}{l}\text { Tournefortia } \\
\text { hartwegiana Steud }\end{array}\end{array}$ & Mangle Rojo & 20392 \\
$\begin{array}{l}\text { Zizyphus obtusifolia } \\
\text { A.Gray }\end{array}$ & Jatachinole & 20388 \\
Forchammeria watsonii & Jito & 20394 \\
$\begin{array}{l}\text { Rose } \\
\text { Lycium berlandier Dunal }\end{array}$ & Barchata & 20393 \\
Vallesia glabra Link & Citabaro & 20388 \\
\hline
\end{tabular}

\section{Amino acid analysis}

Amino acid analysis of plant samples was based on methodology previously reported [10]. Powdered samples $(3 \mathrm{mg})$ were hydrolyzed with $\mathrm{HCl} 6 \mathrm{M}$ at $150^{\circ} \mathrm{C}$ during $6 \mathrm{~h}$. After hydrolysis, the acid was removed by rotary evaporation (RE500 Yamato Scientific America Inc.). Sample was resuspended on $2 \mathrm{~mL}$ of sodium citrate buffer $\mathrm{pH}$ 2.2. Sample derivation was achieved adding $o$-phthalaldehyde (OPA) $7.5 \mathrm{mM}$ to the sample on citrate buffer (OPA reagent contains $\beta$-mercaptoethanol and Brij 35). The HPLC method precision and accuracy was evaluated using external and internal standards. The amino acid reference standard consisted on fifteen amino acids $\left(0.05 \mu\right.$ moles $\mathrm{mL}^{-1}$ each amino acid) and was utilized to determine the retention times for each amino acid. As well, internal standard $\alpha-$ aminobutyric $\left(0.05 \mu\right.$ moles $\left.\mathrm{mL}^{-1}\right)$ was added to amino acid reference standard and each plant sample to normalize and quantify the amino acid content.

A gradient mobile phase of sodium acetate $0.1 \mathrm{M}$ $\mathrm{pH} 7.2$ and methanol (9:1) elute sample for amino acid separation trough $\mathrm{C} 18$ column reversed-phase octadecyl dymethylsilane particles (100 x $4.6 \mathrm{~mm}$ x 1/4" Microsorb 100-3 C18). Fluorescence detection was realized using an excitation-emission wavelength of 360 and $455 \mathrm{~nm}$ respectively. Star Chromatography work station (Varian version 5.51) software was used to achieve amino acid peak integration.

\section{Protein content}

The protein content of each plant was measured to determine amino acid recovery by HPLC using Micro Kjeldahl method [11]. 


\section{Statistical analysis}

Origin 9.0 software (OriginLab Corporation, Northampton, MA 01060 USA) was used for descriptive statistical analysis.

\section{RESULTS}

The plant samples of Jutuki, Jito, Barchata, Citabaro, Mangle rojo and Tatachinole were

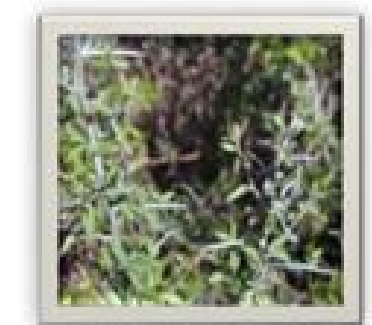

Lycium berlandieri Dunal (Barchata)

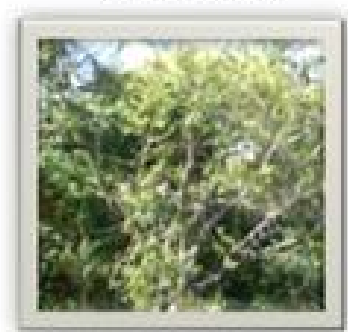

Vallesia glabra Link (Citabaro)
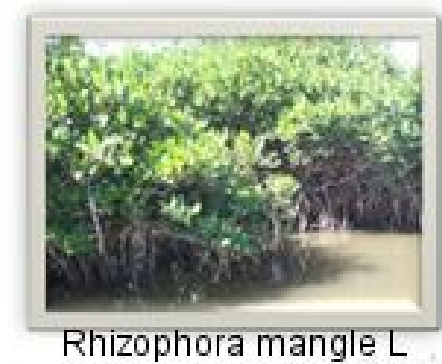

(Mangle rojo)

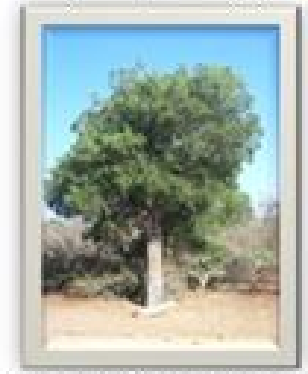

Forchammeria watsonii Rose (Jito) taxonomical characterized on Herbarium of the University of Sonora (Fig.1).

The amino acid profiles of plants from southern Sonora were evaluated using HPLC (Fig 2). The OPA amino acid derivation method allowed identify and quantify fifteen amino acids in each sample, whereas HPLC amino acid analysis resulted in a reliable detection and high peak resolution (Fig 3).

Figure 1: Medicinal plants of southern Sonora used for amino acid analysis

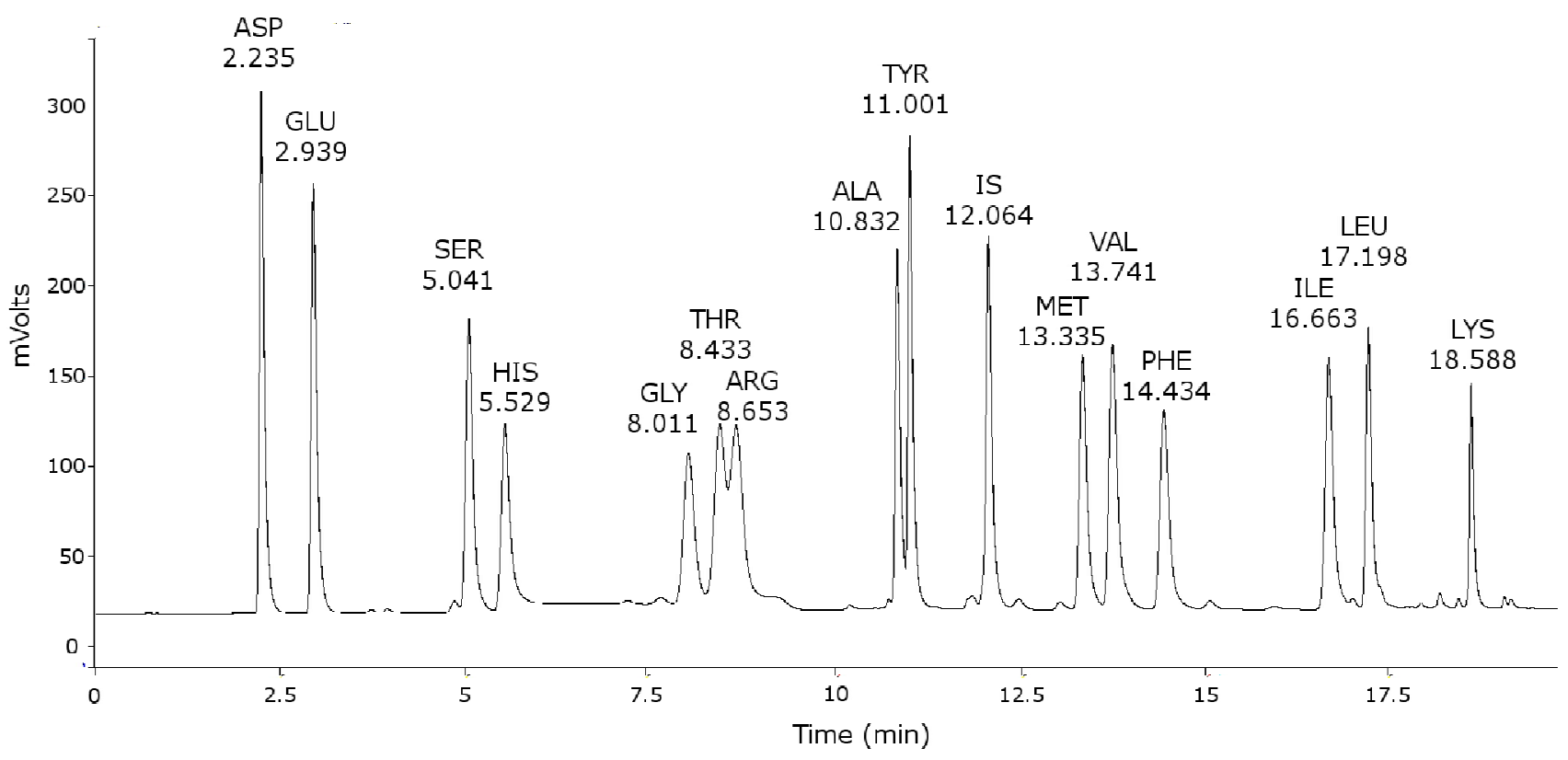

Figure 2: Amino acids standard chromatogram. Note: Each amino acid and internal standard (IS) is identified with the corresponding name and retention time ( $\mathrm{min})$ 


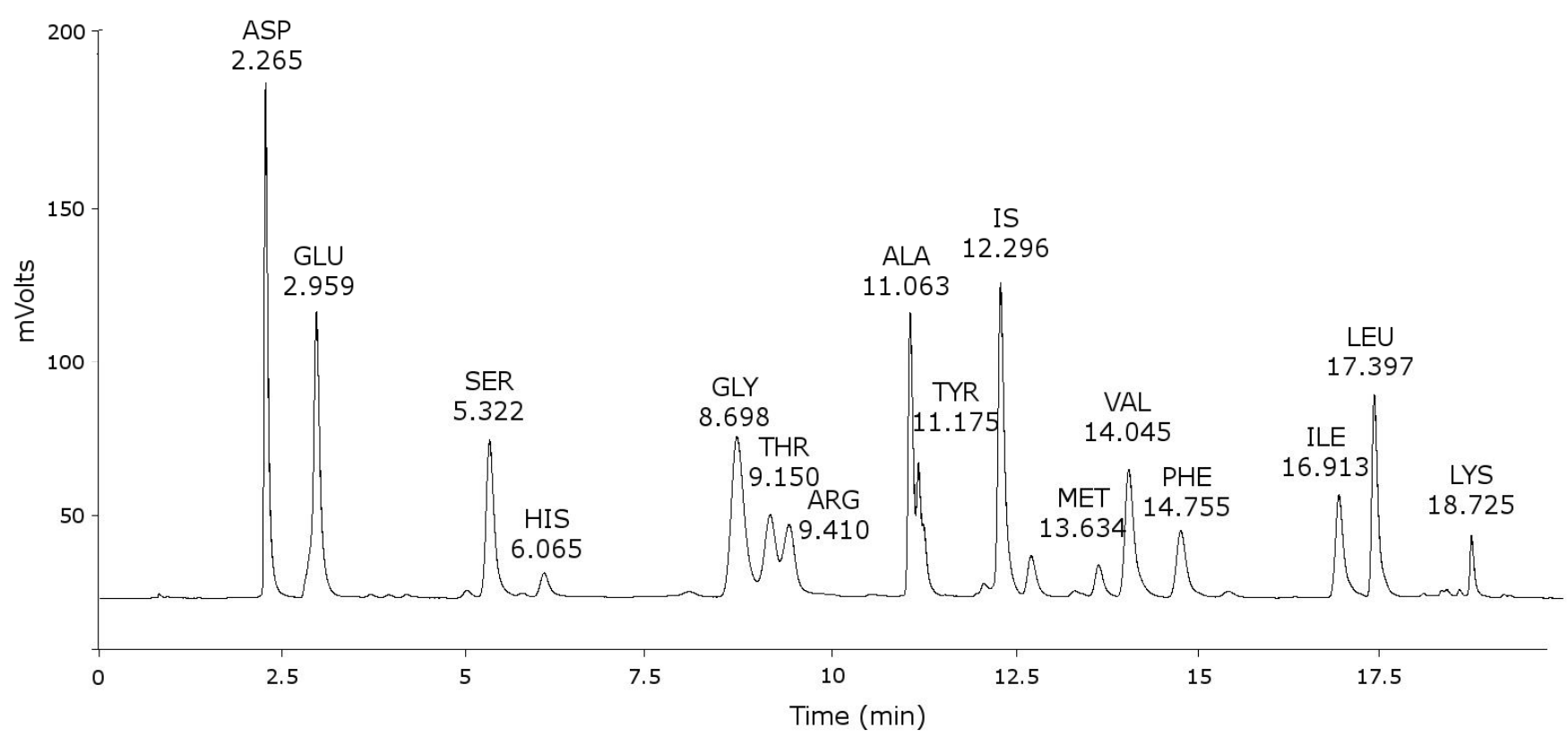

Figure 3: Tatachinole amino acid chromatogram. Note: Each amino acid and internal standard (IS) is identified with the corresponding name and retention time $(\mathrm{min})$

Table 2: Free amino acid concentration (nM) in medicinal plants of Southern Sonora

\begin{tabular}{llllllll}
\hline $\begin{array}{l}\text { Amino } \\
\text { acid }\end{array}$ & $\begin{array}{l}\text { Rhizophora } \\
\text { mangle L } \\
\text { (Leaf) }\end{array}$ & $\begin{array}{l}\text { Rhizophora } \\
\text { mangle L } \\
\text { (bark) }\end{array}$ & $\begin{array}{l}\text { Lycium } \\
\text { berlandieri } \\
\text { Dunal }\end{array}$ & $\begin{array}{l}\text { Zizyphus } \\
\text { obtusifolia A. } \\
\text { Gray }\end{array}$ & $\begin{array}{l}\text { Tournefortia } \\
\text { Steud }\end{array}$ & $\begin{array}{l}\text { Vallesia } \\
\text { glabra Link }\end{array}$ & $\begin{array}{l}\text { Forchammeria } \\
\text { watsonii Rose }\end{array}$ \\
\hline ASP & $22.40 \pm 0.39$ & $10.05 \pm 0.99$ & $14.45 \pm 1.81$ & $35.14 \pm 1.16$ & $43.55 \pm 1.09$ & $38.49 \pm 1.34$ & $17.25 \pm 0.85$ \\
GLU & $21.44 \pm 0.11$ & $10.63 \pm 0.86$ & $15.17 \pm 0.63$ & $9.82 \pm 0.69$ & $44.84 \pm 1.05$ & $26.53 \pm 3.02$ & $14.31 \pm 1.11$ \\
SER & $13.08 \pm 0.62$ & $7.51 \pm 0.33$ & $10.88 \pm 0.78$ & $13.00 \pm 0.96$ & $29.60 \pm 1.27$ & $21.61 \pm 0.93$ & $15.67 \pm 1.83$ \\
HIS & $4.15 \pm 0.06$ & $3.09 \pm 0.28$ & $2.61 \pm 0.32$ & $2.45 \pm 0.11$ & $5.96 \pm 0.12$ & $4.83 \pm 0.27$ & $3.35 \pm 0.32$ \\
GLY & $23.96 \pm 2.34$ & $12.63 \pm 1.00$ & $18.15 \pm 0.94$ & $14.58 \pm 1.05$ & $58.17 \pm 2.84$ & $36.37 \pm 2.85$ & $20.42 \pm 3.68$ \\
THR & $10.10 \pm 0.17$ & $4.69 \pm 0.36$ & $7.20 \pm 0.59$ & $5.87 \pm 0.24$ & $21.90 \pm 0.29$ & $14.13 \pm 0.47$ & $7.69 \pm 0.59$ \\
ARG & $10.06 \pm 0.61$ & $4.09 \pm 0.21$ & $6.18 \pm 0.07$ & $4.54 \pm 0.12$ & $19.21 \pm 0.48$ & $14.95 \pm 0.39$ & $8.20 \pm 0.89$ \\
ALA & $24.03 \pm 1.62$ & $11.03 \pm 0.77$ & $11.96 \pm 0.49$ & $11.74 \pm 0.37$ & $43.05 \pm 2.14$ & $28.89 \pm 1.84$ & $14.74 \pm 1.90$ \\
TYR & $10.79 \pm 0.65$ & $4.15 \pm 0.29$ & $3.20 \pm 0.55$ & $4.96 \pm 0.28$ & $14.53 \pm 0.91$ & $10.80 \pm 0.27$ & $8.26 \pm 2.05$ \\
MET & $4.01 \pm 0.21$ & $2.11 \pm 0.10$ & $2.86 \pm 0.07$ & $2.72 \pm 0.34$ & $7.83 \pm 0.73$ & $4.33 \pm 0.35$ & $2.57 \pm 0.20$ \\
VAL & $15.26 \pm 0.38$ & $7.34 \pm 0.68$ & $10.30 \pm 0.97$ & $7.99 \pm 0.92$ & $28.40 \pm 1.57$ & $18.55 \pm 0.95$ & $11.98 \pm 0.33$ \\
PHE & $9.64 \pm 0.52$ & $4.18 \pm 0.33$ & $5.37 \pm 0.39$ & $3.86 \pm 0.37$ & $18.51 \pm 0.66$ & $11.37 \pm 0.56$ & $5.55 \pm 0.52$ \\
ILE & $11.70 \pm 0.72$ & $5.72 \pm 0.67$ & $7.18 \pm 0.48$ & $6.10 \pm 0.41$ & $23.57 \pm 0.86$ & $14.73 \pm 0.69$ & $8.09 \pm 0.15$ \\
LEU & $20.76 \pm 0.58$ & $9.31 \pm 0.85$ & $10.08 \pm 0.59$ & $7.68 \pm 0.41$ & $38.73 \pm 0.60$ & $23.12 \pm 0.93$ & $10.57 \pm 0.73$ \\
LYS & $9.22 \pm 0.69$ & $4.82 \pm 0.25$ & $6.00 \pm 0.45$ & $5.31 \pm 0.56$ & $12.27 \pm 0.76$ & $11.43 \pm 0.98$ & $5.24 \pm 0.18$ \\
\hline MEn & & & & & & &
\end{tabular}

Mean \pm standard deviation $(n=3)$

The amino acid peak area of standards and samples was calculated to determinate amino acid concentration (Table 2). The leaf of tatachinole plant presented higher amino acid concentrations with 29 to $58 \mathrm{nM}$ and, glycine has the higher concentration, followed by glutamic and aspartic acid, alanine, leucine, serine and valine. The amino acid concentration in citabaro plant was 21 to $38 \mathrm{nM}$ with high concentration of aspartic acid, followed by glycine, alanine, glutamic acid, leucine and serine. The leafs of mangle rojo presented amino acid concentrations of 15 to $24 \mathrm{nM}$ with high concentrations of alanine, followed by glycine, aspartic and glutamic acid, leucine and valine.

The bark sample of jito and root of barchata presented an amino acid concentration of 10 to $20 \mathrm{nM}$ with high concentration of glycine, aspartic acid, serine, alanine, glutamic acid, valine and leucine for bark of jito and glycine, glutamic and aspartic acid, alanine, serine, valine and leucine for the root of barchata. Root of jutuki and bark of mangle rojo presented the lowest amino acid profile concentration among all plants analyzed on this study, with concentrations of 7 to $13 \mathrm{nM}$. Aspartic acid in jutuki samples was the only 
exception due high concentration presented. Amino acid profile concentration order was glycine, serine, alanine, glutamic acid, valine and leucine. For the bark of mangle rojo samples, the amino acid profile was in the concentration order glycine, alanine, glutamic and aspartic acid, leucine, serine and valine (Table 2).

The leaf of tatachinole presented the highest protein concentration $(22.40 \pm 0.42 \%)$ and recovery percent $(83.89 \pm 1.24 \%)$ by HPLC method compared to all plants analyzed. The citabaro plant shows the second higher protein concentration $(19.90 \pm 0.01 \%)$ but with a moderate percent of recovery $(58.50 \pm 1.66 \%)$ that is reflected on their amino acid profile. The bark of jito and root of barchata were third (12.60 $\pm 0.21 \%)$ and fourth $(11.60 \pm 0.14 \%)$ in terms of protein concentration, respectively, but also showed the lowest \% recovery $(39.01 \pm 3.58$ and $42.60 \pm 2.54 \%$, respectively). The mangle rojo (both bark and leaf) and jutuki plants presented the lowest protein concentration $(4.27 \pm 0.21$ and $9.45 \pm 0.07$; and $6.40 \pm 0.42 \%$, respectively) but have the higher percent of recovery $(78.05 \pm$ $5.75,85.25 \pm 1.85$ and $75.71 \pm 1.67 \%$ ) compared to the other samples (Table 3 ).

Table 3: Protein concentration and recovery percent of HPLC free amino acid analysis in plant samples

\begin{tabular}{lll}
\hline Plant sample & $\begin{array}{l}\text { \% Protein } \\
\text { content }\end{array}$ & $\begin{array}{l}\text { Percent of } \\
\text { recovery }\end{array}$ \\
\hline $\begin{array}{l}\text { Rhizophora mangle } L \\
\text { (Leaf) }\end{array}$ & $9.45 \pm 0.07$ & $85.25 \pm 1.85$ \\
$\begin{array}{l}\text { Rhizophora mangle } L \\
\text { (bark) }\end{array}$ & $4.27 \pm 0.21$ & $78.05 \pm 5.75$ \\
$\begin{array}{l}\text { Zizyphus obtusifolia A } \\
\text { Gray (root) }\end{array}$ & $6.40 \pm 0.42$ & $75.71 \pm 1.67$ \\
$\begin{array}{l}\text { Lycium berlandieri Dunal } \\
\text { (root) }\end{array}$ & $11.60 \pm 0.14$ & $42.60 \pm 2.54$ \\
$\begin{array}{l}\text { Tournefortia hartwegiana } \\
\text { Steud (Leaf) }\end{array}$ & $22.40 \pm 0.42$ & $83.89 \pm 1.24$ \\
$\begin{array}{l}\text { Vallesia glabra Link } \\
\text { Forchammeria watsonii } \\
\text { Rose (bark) }\end{array}$ & $19.90 \pm 0.01$ & $58.50 \pm 1.66$ \\
\hline
\end{tabular}

Mean \pm standard deviations $(n=3)$

\section{DISCUSSION}

Secondary metabolism is key to plant adaptation to stress [12]. However, some molecules produced during primary metabolism can participate in stress response and provide plant defense properties. It has been demonstrated that amino acid concentration increases in saltstressed plants [2]. The low precipitation and dry weather of Sonora region expose plants to high temperatures and saline soils [13]. The adaptation of southern Sonora is via the accumulation of molecules in stress response.

Tatachinole sheet and citabaro presented the highest concentration of amino acids. Although citabaro showed high protein concentration, its amino acid content was small to low recovery. Moreover, loss of some amino acids during sample hydrolysis decreased the detection limit of the HPLC method. Therefore, the amino acid content detected in barchata and citabaro, which presented the lowest recovery values (39 and $42 \%$, respectively), might have been underestimated by the technique employed in this work.

Few studies have focused on quantitative amino acid analysis of these medicinal plants. Reports in the literature are related to results of intake or topical functions, which derive from their use in traditional medicine [14]. Fifteen amino acids were detected in each sample, but only aspartic acid (10.63 to $43.55 \mathrm{nM}$ ), glutamic acid (7.51 to $44.84 \mathrm{nM}$ ), serine (3.09 to $29.60 \mathrm{nM}$ ), glycine (4.69 to $58.17 \mathrm{nM}$ ), valine (4.18 to $28.40 \mathrm{nM}$ ), alanine ( 3.20 to $43.05 \mathrm{nM}$ ) and leucine (4.82 to $38.73 \mathrm{nM})$ are present in high concentrations. This is supported by the amino acid profile of Rizophora mangle $L$ where protein/amino acid contents are dominated by acidic amino acids such as aspartic an glutamic acids, followed by neutral amino acids such as glycine [15].

Aspartic acid function is essential for purine, pyrimidine, asparagine and inositol synthesis. Glutamic acid and glycine participate in the synthesis of glutathione increasing the antioxidant capacity of the plant. Valine maintains the balance of branched chain amino acids, whereas alanine is involved on hepatic autophagy, gluconeogenesis and transamination. Leucine regulates the protein turnover (mTOR signaling) and gene expression $[3,16]$.

Glycine, lysine, threonine and glutamate help to maintain intestinal integrity and health $[17,18]$. Jutuki plant is used to treat stomach infections [19] sample, and it showed low amino acid concentration, some of which are related to bowel function, which somehow may explain the medicinal properties of the plant.

Mangle rojo and tatachinole are used in the treatment of urinary tract infections [19]. Amino acids, such as aspartic, are related to detoxification and excretion of ammonia [17]. 
Aspartic acid is present at its highest concentration in tatachinole sheet, as well as in jutuki and citabaro samples.

Amino acids are precursors for the synthesis of secondary metabolites such as alkaloids, which provide chemical defense for plants that confer beneficial physiological effects in consumers. Alkaloids provide protection to plants from a variety of herbivores, and some of them possess significant pharmacological activity such as analgesic, antibacterial and antibiotic [12].

\section{CONCLUSION}

High concentrations of aspartic acid, glutamic acid, serine, glycine, valine, alanine and leucine predominate in all the plants analyzed. Specific metabolic processes in which these amino acids participate may be related to the therapeutic properties of plants as per their use in traditional medicine and, therefore may facilitate the understanding of their beneficial properties. However, further studies are needed to determine and isolate compounds responsible for the specific therapeutic properties of the plants.

\section{ACKNOWLEDGEMENT}

Research was funded by Mexico's National Council for Science and Technology (CONACYT). JARR was gratefully supported by a fellowship. "Apoyos Complementarios para la Consolidación Institucional de Grupos de Investigación: Retención 149021" from CONACYT. The authors also thank Professor José Jesús Sánchez Escalante of Universidad de Sonora Herbarium for helping to authenticate the plant.

\section{REFERENCES}

1. Pérez-Urria CE, Avalos García A. Metabolismo secundario de plantas. REDUCA 2009; 2: 119-145.

2. Cuin TA, Shabala S. Amino acids regulate salinityinduced potassium efflux in barley root epidermis. Planta 2007; 225: 753-761.

3. Wu G. Amino acids: metabolism, functions, and nutrition. Amino Acids 2009; 37: 1-17.

4. Nicastro H, Artioli GG, dos Santos Costa A, Solis MY, da Luz CR, Blachier F, Lancha AH. An overview of the therapeutic effects of leucine supplementation on skeletal muscle under atrophic conditions. Amino Acids 2011: 1-14.

5. Dioguardi FS. Clinical use of amino acids as dietary supplement: pros and cons. J Cachexia Sarcopenia Muscle 2011: 1-6.
6. Vivanco JM, Cosio E, Loyola-Vargas VM, Flores HE. Mecanismos químicos de defensa en las plantas. Investigación y Ciencia 2005; 341: 68-75.

7. Vanisree $M$, Lee C-Y, Lo S-F, Nalawade SM, Lin CY, Tsay $\mathrm{H}$-S. Studies on the production of some important secondary metabolites from medicinal plants by plant tissue cultures. Bot Bull Acad Sin 2004; 45: 1-22.

8. Bautista-Cruz A, Arnaud-Viñas MR, Martínez-Gutiérrez GA, Sánchez-Medina PS, Pacheco RP. The traditional medicinal and food uses of four plants in Oaxaca, Mexico. J Med Plants Res 2011; 5: 34043411.

9. Peinado M, Macías MA, Ocaña-Peinado FM, Aguirre JL, Delgadillo J. Bioclimates and vegetation along the Pacific basin of Northwestern Mexico. Plant Ecol. 2010; 212: 263-281.

10. Vázquez-Ortiz FA, Caire G, Higuera-Ciapara I, Hernández G. High performance liquid chromatographic determination of free amino acids in shrimp. J Liq Chrom 1995; 18: 2059-2068.

11. AOAC. Official Methods of Analysis of Association of Official Analytical Chemists, 15th ed.; AOAC: Arlington, VA, 1990; methods 988.05.

12. Croteau R, Kutchan TM, Lewis NG. Natural products (secondary metabolites). Biochemistry and molecular biology of plants 2000: 1250-1318.

13. Gastélum-Peralta LE, Silva-Olivas MF, Zapata-Moreno MA, Enríquez-Carrillo E, Ramírez Moreno F, IbarraDaniel GD. 2010. Informe Final 2009-2010 de la Unidad Técnica Especializada Pecuaria de la Estrategia de Asistencia Técnica Pecuaria en Sonora.

http://utep.inifap.gob.mx/INF_FINAL_\%202009/SON ORA.pdf)

14. Tapia-Perez ME, Tapia-Contreras A, Cedillo-Rivera R, Osuna L, Meckes M. Screening of Mexican Medicinal Plants for Antiprotozoal Activity-Part II. Pharm Biol 2003; 41: 180-183.

15. Lacerda L, Ittekkot V, Patchineelam S. Biogeochemistry of mangrove soil organic matter: a comparison between Rhizophora and Avicennia soils in southeastern Brazil. Estuar Coast Shelf Sci 1995; 40: 713720.

16. Akram M, Asif H, Uzair M, Akhtar N, Madni A, Shah SMA, ul Hasan Z, Ullah A. Amino acids: A review article. J Med Plants Res 2011; 5: 3997-4000.

17. Rhoads MJ, Wu G. Glutamine, arginine, and leucine signaling in the intestine. Amino Acids 2009; 37: 111 122.

18. Wang W, Qiao S, Li D. Amino acids and gut function. Amino Acids 2009; 37: 105-110.

19. Johnson GD, Moreno SSF, López ER. Compendio fitoquímico de la medicina tradicional herbolaria de Sonora. Universidad de Sonora; 1996. 361 p. 